I am satisfied was a Rosy Finch, and Dr. A. J. Hughes of Fort Qu'Appelle apparently saw one on his premises on two different days at approximately this time. Both observers were attracted by the light, yellowish bill which contrasted with that of the House Sparrows which were also present.

Four Regina enthusiasts, Margaret Belcher, Marjorie Ledingham, Lucy Murray and Holly Wallace, came out to Fort San on March 9 and the birds co-operated beautifully. Dr. and Mrs. Jenner were supplying a mixture of ground suet, peanut butter and sometimes cracked grain in a feeder on a window sill and the birds were tame enough that an observer on the inside could watch them from a distance of probably ten feet and sometimes less. The Regina group watched them for almost an hour as they came once or twice to feed on the window sill or as they fed on seeds in the flower garden at the base of the hill beside the house.

Dr. and Mrs. Jenner have made the following interesting observations concerning their feathered visitors:

(a) From the beginning they were fairly tame but as the weeks went by the birds became even more confiding.

(b) When feeding they were usually in competition with the House Sparrows and showed considerable aggressiveness; on only one cccasion was a sparrow seen to contest the issue.

(c) During the last few weeks that they were present, the rosy colour of the birds became brighter and more easily seen.

As most of our readers will know, the normal home of the Rosy Finch is in the mountains of Western Canada and United States and it is rarely seen in Saskatchewan. Evidence of this is indicated by the following recorded observations:

May, 1827-specimen taken near the Saskatchewan River between Saskatoon and Prince Albert (probably near Carlton).

November 26, 1921, January 20, 1922, and March 16, 1922-specimens taken at Eastend. Noted in several years.

Prior to 1924 -repeated observations at Indian Head.

March 1, 1933-"many seen" at Ravenscray (Spencer Pearse).

January, 1934-"bands" at Eastend (L. B. Potter)

February 26, 1934-specimen taken at Dollard by Charles F. Holmes.

October 23, 1940-sight record of one bird at Regina.

Ea:ly December, 1940-one seen for several days in Nipawin area.

Early winter, 1948-specimen taken at Regira.

June 3, 1953-sight record of one bird in Nipawin area.

October 20, 1962-sight record of one bird at Saskatoon.

February 2 - April 3, 1963-two males observed regularly in Fort Qu'Appelle area.

Details of the various observations may be found in The Birds of the Saskatchewan River (Houston and Street, 1959), Catalogue of the birds of Saskatchewan (Mitchell, 1924), Birds of Regina (Belcher, 1961), in the Blue Jay (21:12), in the references which those publications have quoted, and in the SMNH files.

It will be noted that there have been only six recorded observations in Saskatchewan in the last 25 years or more. This winter we have other reports from outside Saskatchewan of Rosy Finches east of their usual range. In southwestern South Dakota (Black Hills area) they appeared mid-January to mid-February, with 80 counted by L. Baylor near Hill City, South Dakota, on February 17, 1963; and near Lethbridge, Alberta, T. H. Bassett sighted one on March $30,1963$.

\title{
First Record of Wood Duck for Regina Area
}

\section{by Margaret Belcher and Doug Gilroy, Regina}

On November 24, 1962, Albert Swanston of the Saskatchewan Museum of Natural History, found a female Wood Duck (Aix sponsa) in one of his mink traps along the Boggy Creek, three-quarters of a mile from the buildings on Doug Gilroy's farm 14 miles northwest of Regina. The duck was removed from the trap and shown to Doug Gilroy, and it was identified as a Wood Duck. This duck is considered rare in any part of the prairies, and neither Swanston nor Gilroy had seen one before, so several bird books were brought out io confirm the identification. The duck was then submitted to the Saskatchewan Museum of Natural History for preparation as a study skin.

The summer range of the Wood 


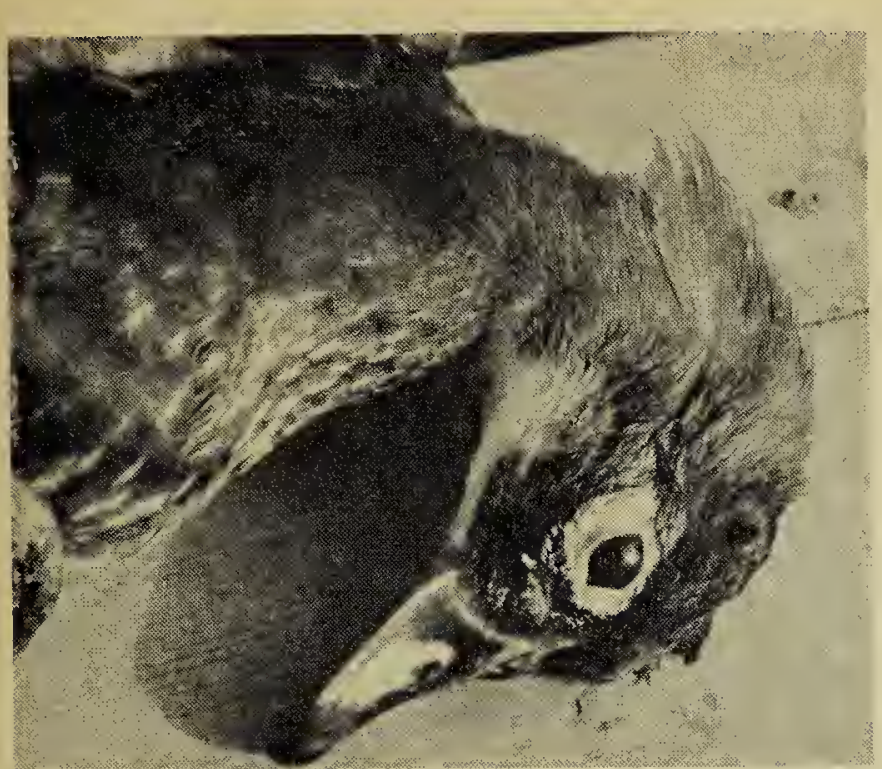

Photo by Doug Gilroy.

Head of female Wood Duck, taken at Boggy Creek, November 24, 1962.

Duck includes southern Canada, but since it is a tree-nesting duck and frequents woodland lakes and ponds, its distribution in Saskatchewan is limited. Houston and Street in The Birds of the Saskatchewan River (Spec. Publ. No. 2, S.N.H.S., 1959) give the record of a male taken at Cumberland House, June, 1827 (Richardson) and of a nest found with one egg and forwarded to Washington in early June, 1890 (MacFarlane). Also cited is the record of a specimen in the Smithsonian Institution, an adult male collected at Pas Mountain [Red Earth; on the Carrot River, 30 miles from Cumberlandl in June, 1890. H. H. Mitchell's Catalogue of the birds of Saskatchewan (Can. Field-Nat., 38:101-118, May, 1924) refers to Lang's report of a "pair breeding in a hollow tree at Deep Lake, 7 miles south of Indian Head, in 1888", and gives two early records of specimens taken by George Lang at the Qu'Appelle Lakes, Ortober 18, 1899 .

Records from the S.M.N.H. files include sight records for Hudson Bay Junction-seen in 1923 by H. H. Mitchell and one seen June 18, 1923, by George Revell; and one seen in June, 1939 , on the Waskwei River, Pasquia Forest Reserve, which R. D. Symons and F. G. Bard felt sure was a Wood Duck, although they only glimpsed it fleetingly. The S.M.N.H. files also record a male taken at Carrot River (Sec. 4-53-6 W2) on May 9, 1944, by R. A. Hutton of Red Earth, this specimen being taken to the Pas, Manitoba, where it was destroyed by mice.
From personal correspondence with J. B. Gollop, Canadian Wildlife Service, Saskatoon, come two more recent records: F. A. Thompson, U.S. Fish and Wildlife Service, banded one Wood Duck on Big Muddy Lake between June 30 and August 14, 1953; Saskatoon observers, including J. B. Gollop, had a pair under observation on the creek at Pike Lake in 1959, from May 3-24 (first noted by Bob Folker).

The Wood Duck caught in Swanston's mink trap could have come from a breeding population in northeast Saskatchewan, but it is perhaps more likely that it was a straggler from the west or southwest. There may be a parallel to be drawn between the finding of a Wood Duck on November 24 and the appearance of two male Hooded Mergansers at the Regina Waterfowl Park on November 20 (reported by Belcher, L. H. Murray). According to Audubon Field Notes, 17:42, a large flock of 145 Hooded Mergansers appeared at Kenmare, North Dakota, on September 28, 1962, remained for almost two months, and then suddenly disappeared on November 19. On the following day, November 20, our two birds appeared at Regina, and on November 24 one was reported from Jamestown, North Dakota-which might represent the dispersal of the group at Kenmare. The Wood Duck at Boggy Creek could have been part of a similar dispersal movement rather than a bird following a northsouth migration path.

The Wood Duck is considered an early autumn migrant, moving south in September and the early part of October (F. H. Kortright, The ducks, geese and swans of North America, Washington, Wildlife Management Institute, 1942). The late date of its appearance in the Regina area is probably related to the unusually open fall. In most parts of the Northern Great Plains Region the 1962 fall migration was late, with numerous species noted as staying much later than is normal. A new area record of the Wood Duck for El Paso, Texas, on November 24, 1962 (Audubon Field Notes) is closely related to our date, but the Martin County, Texas, arrival date of November 3,1962 , does indicate that at least part of the migration was on a more usual schedule. 